\title{
Molecular pharmacology of antihistamines in inhibition of oxidative burst of professional phagocytes
}

\author{
Radomír Nosál, Viera Jančinová, Katarína Drábiková and Tomáš Perečko \\ Department of Cellular Pharmacology, Institute of Experimental Pharmacology and Toxicology, Slovak Academy of Sci- \\ ences, Bratislava, Slovak Republic
}

\begin{abstract}
Antihistamines of the $\mathrm{H}_{1}$ and $\mathrm{H}_{3} / \mathrm{H}_{4}$ groups interfere with oxidative burst of human professional phagocytes in vitro. In the concentration of $10 \mu \mathrm{M}, \mathrm{H}_{1}$ antihistamines of the $1^{\text {st }}$ and $2^{\text {nd }}$ generation inhibited oxidative burst of human neutrophils in the rank order of potency: dithiaden $>$ loratadine $>$ brompheniramine $>$ chlorpheniramine $>$ pheniramine. Of the $\mathrm{H}_{1}$ antihistamines, the most effective was dithiaden in suppressing oxidative burst of whole human blood and dosedependently the chemiluminescence of isolated neutrophils at extra- and intracellular level. Inhibition of free oxygen radical generation in isolated neutrophils by dithiaden resulted from the inhibition of protein kinase $\mathrm{C}$ activation. The potentiation of recombinant caspase- 3 by dithiaden is supportive of the antiinflammatory effect of dithiaden and suggestive of increasing the apoptosis of professional phagocytes. Of the $\mathrm{H}_{3} / \mathrm{H}_{4}$ antihistamines, the most effective was JNJ7777120 in decreasing chemiluminescence in whole blood and also at extra- and intracellular sites of isolated neutrophils. JNJ 10191584 and thioperamide were less effective and the latter significantly potentiated free oxygen radical generation intracellularly. The results demonstrated that, compared with the $\mathrm{H}_{3} / \mathrm{H}_{4}$ antihistamines investigated, $\mathrm{H}_{1}$ antihistamines were much more potent in inhibiting free oxygen radical generation in human professional phagocytes. This finding should be taken into account therapeutically.
\end{abstract}

Key words: Professional phagocytes - Oxidative burst - Chemiluminescence - Antihistamines - Protein kinase C - Recombinant caspase-3

\begin{abstract}
Abbreviations: BPA, brompheniramine; CL, chemiluminescence; CPA, chlorpheniramine; DITH, dithiaden; HIST, histamine; LOR, loratadine; PA, pheniramine; PKC, protein kinase C; ROS, reactive oxygen species; THIO, thioperamide.
\end{abstract}

\section{Introduction}

Antihistamines represent a wide range of medicinal drugs and experimentally used chemicals with defined affinity to four histamine receptors. In addition to their specific activity (Leurs et al. 2002, 2011; Parsons and Ganellin 2006; Church and Church 2013) in different tissues and organs, antihistamines possess many pharmacological side effects resulting from their

Correspondence to: Radomír Nosál, Department of Cellular Pharmacology, Institute of Experimental Pharmacology and Toxicology, Slovak Academy of Sciences, Dúbravská 9, 84104 Bratislava, Slovak Republic

E-mail: radomir.nosal@savba.sk non-specific activities (Nosál' 2006a). $\mathrm{H}_{1}$-antihistamines of the 1 st and 2 nd generation, Dithiaden ${ }^{\mathrm{R}}$ and Loratadine ${ }^{\mathrm{R}}$, inhibited platelet aggregation by interfering with platelet phospholipase $\mathrm{A}_{2}$ (Nosál and Jančinová 2002a), decreased the release of GMCSF and IL-8 in granulocyte-macrophage colony (Cheng et al. 2006), and dose-dependently decreased polymorphonuclear leukocyte chemiluminescence (CL) and aggregation (Nosál' et al. 2002b). Differences exist between $\mathrm{H}_{1}$-antihistamines in suppressing the extra- and intracellular stimulated CL, suggesting both extracellular scavenging of generated reactive oxygen species and interference with intracellular regulatory pathways in neutrophils (Nosál' et al. 2009a). The antiradical effect of antihistamines was stimulus-dependent. While dithiaden (DITH) inhibited dose-dependently CL of isolated 
neutrophils stimulated with phorbol-myristateacetate, calcium ionophore A23187 and opsonized zymosan, the inhibition of fMLP-stimulated CL was biphasic (Nosál' et al. 2002b).

Moreover, $\mathrm{H}_{1}$-antihistamines were found to improve ischaemia/reperfusion injury in rat mesenteric microcirculation by suppressing oxidative burst of blood phagocytes, particularly neutrophils (Nosál' et al. 2009b; Nosálová et al. 2009). Differences in the effect of $\mathrm{H}_{1}$-antihistamines on oxidative burst and nitric oxide production of professional phagocytes depend on their physico-chemical properties and are related to the dissociation rate at acidic $\mathrm{pH}$ (Gillard and Chatelain 2006; Králová et al. 2008, 2009).

On the other hand, pheniramines differ in suppressing the generation of reactive oxygen species of human professional phagocytes as a result of halogenisation (Jančinová et al. 2006), corresponding to the inclusion of complexes of beta-cyclodextrin into pheniramine and its halogenated derivative (Wang 2009).

Histamine $\mathrm{H}_{3}$-receptors act as presynaptic autoreceptors that inhibit the synthesis and release of histamine in histaminergic neurones in the central nervous system (CNS). They also occur as hetero-receptors on nonhistaminergic neurones, modulating the release of other neurotransmitters such as 5-hydroxytryptamine, dopamine, acetylcholine, noradrenaline and GABA in the CNS and periphery. Ligands for the $\mathrm{H}_{3}$-receptor have been reviewed (Celanire et al. 2005; Passani and Blandina 2011).

The $\mathrm{H}_{4}$ receptor is preferentially expressed in various cells of the immune system and mast cells and induces the chemotaxis of, for example, eosinophils and mast cells. It has also been identified on lymphocyte $\mathrm{T}$ cells, dendritic cells and basophils. The $\mathrm{H}_{4}$-receptor has been suggested to be involved, along with the $\mathrm{H}_{2}$-receptor, in the control of IL-16 release from human lymphocytes, and it has been speculated that an $\mathrm{H}_{4}$-selective antagonist might be useful in helping to treat asthma. Antagonists, such as JNJ7777120 were also reported to be effective in various models of inflammation (Thurmond et al. 2008; Smith et al. 2009).

In this study, the effect of $\mathrm{H}_{1}$-antihistamines of the first generation, i.e. dithiaden, pheniramine, brompheniramine and chlorpheniramine, and of the second generation, loratadine was compared with the effect of the $\mathrm{H}_{3}$-antihistamine thioperamide and $\mathrm{H}_{4}$-antihistamines JNJ7777120, JNJ 10191584 on oxidative burst of human whole blood and isolated neutrophils in vitro.

\section{Materials and Methods}

\section{Chemicals}

Luminol, isoluminol, PMA (phorbol-4 $\beta$-12 $\beta$-myristate$13 \alpha$-acetate), superoxide dismutase, dextran (average MW
464,000), zymosan A (from Sacharomyces cerevisiae), luciferase (from firefly Photinus pyralis) and D-luciferin sodium salt from Sigma-Aldrich Chemie (Deisenhofen, Germany). HRP (horseradish peroxidase), catalase and Folin-Ciocalteu's phenol reagent were purchased from Merck (Darmstadt, Germany) and lymphoprep (density $1.077 \mathrm{~g} /$ $\mathrm{ml}$ ) from Nycomed Pharma AS (Oslo, Norway), human purified caspase-3 was from Enzo Life Sciences (Lausen, Switzerland). All other chemicals used were of analytical grade and obtained from commercial sources.

The phosphate buffered saline solution (PBS) used in this study contained $136.9 \mathrm{mM} \mathrm{NaCl}, 2.7 \mathrm{mM} \mathrm{KCl}, 8.1 \mathrm{mM}$ $\mathrm{Na}_{2} \mathrm{HPO}_{4}, 1.5 \mathrm{mM} \mathrm{KH}_{2} \mathrm{PO}_{4}, 1.8 \mathrm{mM} \mathrm{CaCl}_{2}$ and $0.5 \mathrm{mM}$ $\mathrm{MgCl}_{2} \times 6 \mathrm{H}_{2} \mathrm{O}(\mathrm{pH}=7.4)$. Tyrode's solution used in this study consisted of $136.9 \mathrm{mM} \mathrm{NaCl}, 2.7 \mathrm{mM} \mathrm{KCl}, 11.9 \mathrm{mM}$ $\mathrm{NaH}_{2} \mathrm{CO}_{3}, 0.4 \mathrm{mM} \mathrm{NaH}_{2} \mathrm{PO}_{4} \times 2 \mathrm{H}_{2} 0,1 \mathrm{mM} \mathrm{MgCl}_{2} \times 6 \mathrm{H}_{2} \mathrm{O}$ and $5.6 \mathrm{mM}$ glucose, $\mathrm{pH}$ of 7.4 .

\section{Antihistamines}

Dithiaden (DITH): 4-[3-(dimethylamino) propylidene]4,9-dihydrothieno [2,3-b]benzo[e]thiepin, Zentiva, Czech Republic; Loratadine (LOR): ethyl 4-(8-chloro5,6-dihydro-11H-benzo[5,6]cyklohepta[1,2-b]pyridin11-ylidene)-1-piperidinecarboxylate, Zentiva, Slovak Republic; Brompheniramine (BPA): 3-(4-bromophenyl)N,N-dimethyl-3-pyridin-2-yl-propan-1-amine, Weyth, Austria; Chlorpheniramine (CPA): 3-(4-chlorphenyl)N,N-dimethyl-3-pyridin-2-yl-propan-1-amine, Glaxo, Smithkline, Great Britain; Pheniramine (PA): N,N-dimethyl-3-phenyl-3-pyridin-2-yl-propan-1-amine, Hoechst, Germany; JNJ7777120: 5-chloro-2-[(4-methylpiperazin-1yl)carbonyl]-1H-imidole and JNJ 10191584: 1-[(5-chloro1H-benzimidazol-2-yl)carbonyl]-4-methylpiperazine maleate, Sigma-Aldrich; Thioperamide (THIO): Ncyklohexyl-4-(imidazol-4-yl)-1-piperidinecarbothioamide maleate, Abcam Biochemicals.

\section{Blood collection and neutrophil separation}

Fresh human blood was obtained at the blood bank by venepuncture from healthy male volunteers (20-50 years) who had not received any medication for at least 7 days. It was anticoagulated with $3.8 \%$ trisodium citrate (blood:citrate ratio $=9: 1$ ). The Ethical Committee license for blood sampling was registered at the National Transfusion Service NTS-KRA/2012/SVI. Human neutrophils were isolated from whole blood, as described previously (Jančinová et al. 2009; Nosál' et al. 2011). The blood was gently mixed and erythrocytes were allowed to sediment in $3 \%$ dextran solution by centrifugation $\left(10 \times g, 25 \mathrm{~min}, 22^{\circ} \mathrm{C}\right)$. The neutrophil suspension was layered on Lymphoprep $(3 \mathrm{ml})$ and centrifuged $\left(500 \times g, 30 \mathrm{~min}, 22^{\circ} \mathrm{C}\right)$. After hypotonic lysis and 
centrifugation $\left(500 \times g, 10 \mathrm{~min}, 22^{\circ} \mathrm{C}\right)$, the neutrophils were resuspended in $\mathrm{Ca}^{2+}-\mathrm{Mg}^{2+}$-free PBS. After counting, they were adjusted to a final concentration of $10^{5}$ cells/ $\mu$ (Coulter Counter, Coulter Electronics, England) and kept on ice. The final suspension of neutrophils contained more than $96 \%$ of viable cells, as evaluated by trypan blue exclusion and was used within $2 \mathrm{~h}$, as long as the control chemiluminescence remained constant.

\section{Chemiluminescence (CL) assay of whole blood and isolated neutrophils}

The oxidative burst in whole blood was stimulated with phorbolmyristate acetate (PMA $0.05 \mu \mathrm{M}$ ). CL was measured in $250 \mu \mathrm{l}$ samples consisting of $50 \mu \mathrm{l}$ aliquots that contained blood $(50 \times$ diluted $)$, luminol $(250 \mu \mathrm{M})$, antihistamines $(\mathrm{AH} ; 0.01-100 \mu \mathrm{M})$ and phosphate buffer (Jančinová et al. 2009). Horseradish peroxidase (HRP 8 U/ $\mathrm{ml}$ ) was added to the system and maintained a sufficient extracellular peroxidase concentration. The effect of $\mathrm{AH}$ on extra- and intracellular reactive oxygen species (ROS) production was measured in unstimulated and PMA $(0.05 \mu \mathrm{M})$-stimulated neutrophils $\left(5 \times 10^{5}\right.$ per sample $)$ by isoluminol/luminol-enhanced CL. Extracellular CL was determined in the system containing isoluminol $(5 \mu \mathrm{M})$ and HRP $(8 \mathrm{U} / \mathrm{ml})$. Intracellular $\mathrm{CL}$ was measured with luminol in the presence of extracellular scavengers - superoxide dismutase $(100 \mathrm{U} / \mathrm{ml})$ and catalase $(2000 \mathrm{U} /$ ml) (Drábiková et al. 2009). The CL of both whole blood and isolated neutrophils was evaluated in a microplate luminometer Immunotech LM-01T (Czech Republic) at $37^{\circ} \mathrm{C}$. The data were based on integral values of CL over $3600 \mathrm{~s}$ (whole blood) or $1800 \mathrm{~s}$ (isolated neutrophils) $(\mathrm{RLU} \times \mathrm{s}$; RLU, relative light units).

\section{Recombinant caspase-3 activity}

To determine the caspase-3-activity, a modified method was applied (Perečko et al. 2010). Briefly, the cleavage of the Z-DEVD-amino-luciferin substrate by caspase releases amino-luciferin. The subsequent reaction with luciferase was detected by CL. The light production was measured in the Luminometer Immunotech LM-01T. According to the manufacturer's instructions, $10 \mu \mathrm{l}$ of $0.1 \mathrm{IU}$ caspase was added to $20 \mu \mathrm{l}$ aliquots of different DITH concentrations and buffered solution. Finally, $50 \mu \mathrm{l}$ of Caspase-Glo 3/7 Reagent was added and the mixture was measured for $60 \mathrm{~min}$ to determine caspase- 3 activity.

\section{Protein kinase $C$ activation}

Phosphorylation of protein kinase C (PKC) isoenzymes $\alpha$ and $\beta$ II was detected (Jančinová et al. 2009). Isolated human neutrophils $\left(5 \times 10^{6}\right)$ were incubated at $37^{\circ} \mathrm{C}$ with DITH for $1 \mathrm{~min}$, stimulated with PMA $(0.15 \mu \mathrm{M}, 1 \mathrm{~min})$ and lysed by the addition of solubilisation buffer. After sonication on ice, the samples were centrifuged to remove unbroken cells, the supernatant was boiled for $5 \mathrm{~min}$ with sample buffer and the samples were loaded on 9.8\% SDS polyacrylamide gels. Proteins were separated by electrophoresis, transferred to Immobilon-P Transfer Membrane (Millipore Corp., USA). From the two strips taken, one was detected for PKC and the second for $\beta$-actin, which represented the internal control. Membrane strips were blocked for 60 min with $1 \%$ bovine serum albumin in Tris buffered saline. This was followed by $60 \mathrm{~min}$ incubation in the presence of the Phospho-PKC $\alpha$ and $\beta$ II (Thr638/641) antibody (rabbit anti-human, 1:8000, Cell Signaling Technology) or $\beta$-actin Antibody (rabbit anti-human, 1:4000, Cell Signaling Technology, Danvers, MA, USA). The membranes were subsequently washed six times with TBS and incubated for 60 min with the secondary antibody conjugated to horseradish peroxidase (anti-rabbit from donkey, 1:10 000, Amersham, UK). The activity of horseradish peroxidase was visualised using Enhanced Chemiluminiscence Western Blotting Detection Reagents (Amersham, UK), followed by autoradiography. The optical density of each PKC band was corrected by the optical density of the corresponding $\beta$-actin band.

\section{Statistical analysis}

Data represent the mean \pm SEM, unless stated otherwise. Statistical analysis was performed using the ANOVA paired test to examine differences between the treatments and control. Differences were considered to be statistically significant when $\left.p<0.05{ }^{*}\right)$ or $p<0.01\left(^{* *}\right)$.

\section{Results}

The dose-dependent effect of histamine and antihistamines studied on whole blood chemiluminescence (CL) stimulated with PMA $(0.05 \mu \mathrm{M})$ is demonstrated in the Figure 1 . In concentrations of $0.1,1.0,10$, and $100 \mu \mathrm{M}$, the most effective was DITH followed by BPA, CPA and JNJ7777120. LOR was active in the highest concentration used. Histamine was without effect and THIO decreased CL in $100 \mu \mathrm{M}$ concentration by $20 \%$. JNJ 10191584 , on the other hand, potentiated CL in the highest concentration by $20 \%$.

Figure 2 shows the dose-dependent effect of histamine and eight antihistamines tested on extracellular isoluminolenhanced CL of isolated neutrophils stimulated with PMA $(0.05 \mu \mathrm{M})$. DITH, LOR, PA, BPA, CPA and histamine decreased extracellular CL in concentration-dependent manner, JNJ 10191584 and THIO had no effect. DITH and 


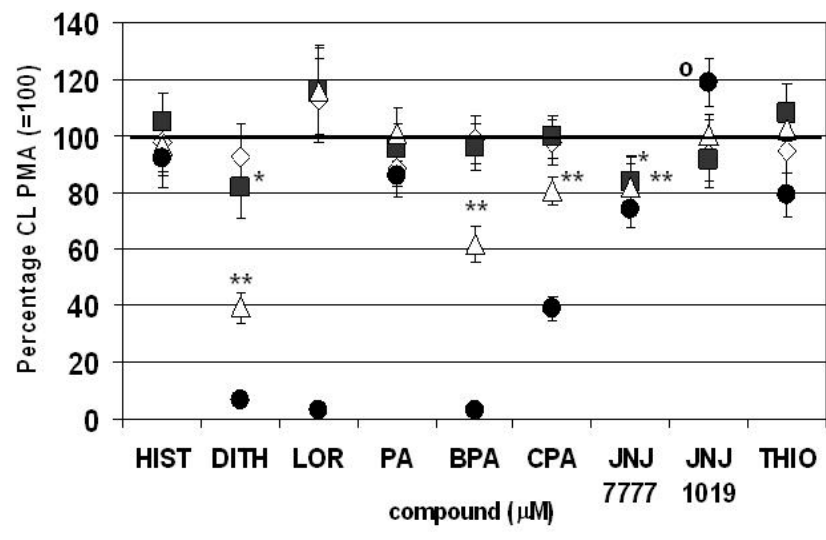

$\diamond 0.1 \square 1.0 \triangle 10 \bullet 100$

Figure 1. Effect of histamine (HIST) and antihistamines dithiaden (DITH), loratadine (LOR), pheniramine (PA), brompheniramine (BPA), chlorpheniramine (CPA), JNJ7777120, JNJ 10191584 and thioperamide (THIO) on human whole blood luminol-enhanced chemiluminescence (CL) expressed as percent CL of PMA (phorbol$4 \beta$ - $12 \beta$-myristate- $13 \alpha$-acetate, $0.05 \mu \mathrm{M}$ ) stimulation. Data are mean $\pm \operatorname{SEM}(n=4-6),{ }^{*} p<0.05 ;{ }^{* *} p<0.01 ;{ }^{\mathbf{o}} p>0.01$.

LOR in $100 \mu \mathrm{M}$ concentration completely inhibited PMAstimulated CL. Due to JNJ7777120; a significant decrease in CL by $40 \%$ CL started at $0.1 \mu \mathrm{M}$ concentration.

The effect of histamine and antihistamines tested on intracellular CL of isolated neutrophils stimulated with

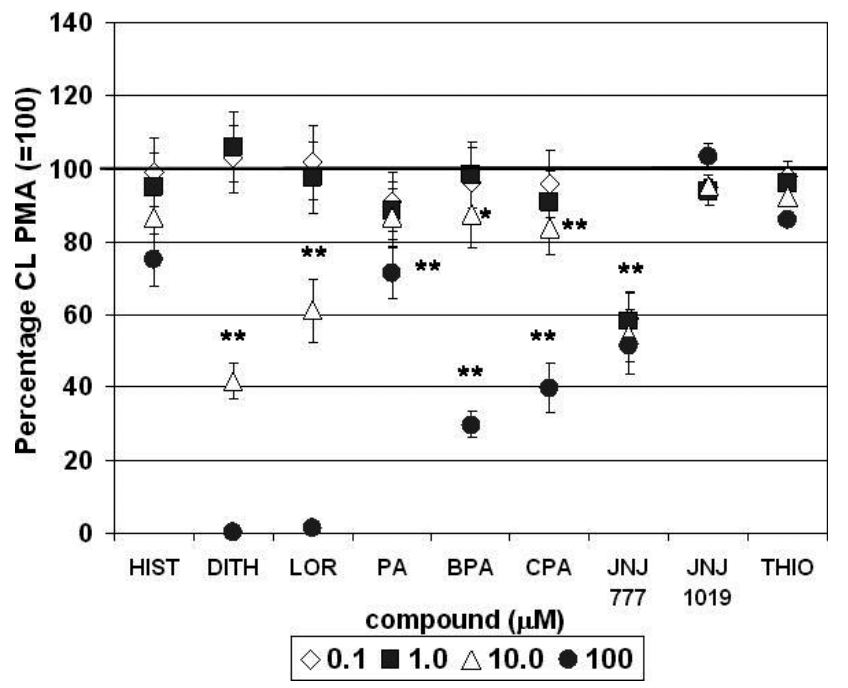

Figure 2. Effect of histamine and antihistamines dithiaden, loratadine, pheniramine, brompheniramine, chlorpheniramine, JNJ7777120, JNJ 10191584 and thioperamide on human neutrophil extracellular isoluminol-enhanced chemiluminescence expressed as percent of PMA $(0.05 \mu \mathrm{M})$ stimulation. Data are mean \pm SEM $(n=4-6),{ }^{\star} p<0.05 ;{ }^{* *} p<0.01$. For abbreviations see Fig. 1.
PMA $(0.05 \mu \mathrm{M})$ is shown in the Figure 3. DITH and LOR dose-dependently decreased CL with complete inhibition at $100 \mu \mathrm{M}$ concentration. Histamine, PA, BPA, CPA and JNJ 10191584 had no effect in any concentration used, JNJ7777120 decreased CL by $40 \%$ at $100 \mu \mathrm{M}$ concentration. THIO in $100 \mu \mathrm{M}$ concentration potentiated CL by $75 \%$.

The effect of histamine and antihistamines tested, expressed as the mean of four concentrations used, on the percentage of PMA-stimulated CL (=100\%) in whole blood (WB), extracellular and intracellular level is summarised in Figure 4. The rank order of potency for inhibition of WB CL was: $\mathrm{DITH} \geq \mathrm{BPA}>\mathrm{CPA}>\mathrm{JNJ7777120}>$ LOR. PA, THIO, histamine and JNJ 10191584 had a minor or no effect.

For extracellular inhibition of stimulated CL the following rank order of potency was evaluated: JNJ7777120 $>$ DITH $>$ LOR $>$ CPA $>$ BPA $>$ PA $>$ histamine $>$ THIO. JNJ 10191584 was without any effect.

At the intracellular level, tested compounds decreased CL in the following rank order of potency: DITH > LOR > JNJ7777120 > JNJ 10191584. Histamine, PA, BPA and CPA were ineffective, while THIO significantly potentiated CL.

Table 1 summarizes the $\mathrm{ED}_{50}$ values calculated from four concentrations used for percentage inhibition of CL with histamine and the antihistamines tested and stimulated with PMA. The most effective was DITH with 5.7, 8.2 and $16 \mu \mathrm{M}$ concentrations for whole blood, extra- and intracellular CL, respectively. LOR was the second most effective compound. For histamine and for the other antihistamines tested the $\mathrm{ED}_{50}$ values for whole blood, extra and intracellular CL were unequivocal.

DITH increased significantly the activity of human recombinant caspase 3 starting at the concentration of $1 \mu \mathrm{M}$

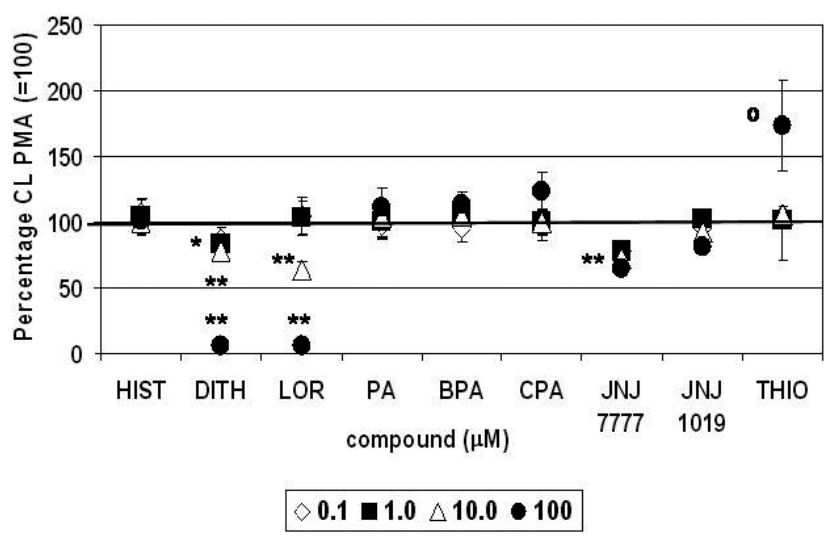

Figure 3. Effect of histamine and antihistamines dithiaden, loratadine, pheniramine, brompheniramine, chlorpheniramine, JNJ7777120, JNJ 10191584 and thioperamide on human neutrophil intracellular luminol-enhanced chemiluminescence expressed as percent of PMA $(0.05 \mu \mathrm{M})$ stimulation. Data are mean $\pm \operatorname{SEM}(n=4-6),{ }^{\star} p<0.05$; ${ }^{* *} p<0.01,{ }^{\mathbf{o}} p>0.01$. For abbreviations see Fig. 1. 


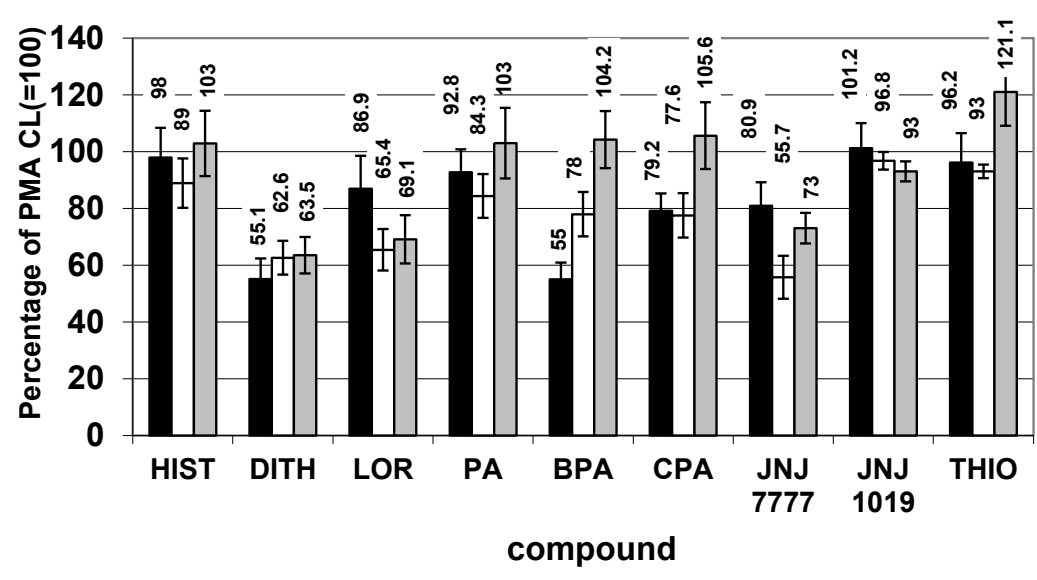

-WB 口Extracell 口Intracell
Figure 4. Effect of histamine and antihistamines dithiaden, loratadine, pheniramine, brompheniramine, chlorpheniramine, JNJ7777120, JNJ 10191584 and thioperamide expressed as the mean of all four concentrations $(0.1 ; 1.0 ; 10$; $100 \mu \mathrm{M})$ used on percentage of PMA-stimulated CL $(=100 \%)$ in human whole blood (WB), extracellular and intracellular level of isolated neutrophils. Data are mean $\pm \operatorname{SEM}(n=4-6)$. For abbreviations see Fig. 1.
(Figure 5). The caspase-3 activity increased with DITH in concentrations of 1,10 and $100 \mu \mathrm{M}$ by $25.2,29.8$ and $32.3 \%$ of the control value, respectively.

Stimulation of isolated human neutrophils with PMA $(0.15 \mu \mathrm{M})$ resulted in the increase protein kinase $\mathrm{C} \alpha$ and $\beta$ II by $34 \%$ (Figure 6). Dithiaden in concentrations of 10 and $100 \mu \mathrm{M}$ decreased stimulated phosphorylation by 21 and $22 \%$, respectively.

\section{Discussion}

The antihistamines studied of the $\mathrm{H}_{1}$ and $\mathrm{H}_{3} / \mathrm{H}_{4}$ group affected oxidative burst of human professional phagocytes in vitro. In the concentration of $10 \mu \mathrm{M}$, the antihistamines tested inhibited oxidative burst of whole blood CL in the rank order of potency: dithiaden $>>$ brompheniramine $>$ chlorpheniramine $=$ JNJ7777120. At the extracellular site

Table 1. Micromolar $\mathrm{ED}_{50}$ values calculated from concentrations $(0.1,1.0,10$ and $100 \mu \mathrm{M})$ of used compounds

\begin{tabular}{lccc}
\hline \multirow{3}{*}{ Compound } & \multicolumn{3}{c}{$\mathrm{ED}_{50}(\mu \mathrm{M})$} \\
\cline { 2 - 4 } & whole blood & extracellular & intracellular \\
\hline Histamine & n.d. & $>100$ & n.d \\
Dithiaden & $\mathbf{5 . 7}$ & $\mathbf{8 . 2}$ & $\mathbf{1 6}$ \\
Loratadine & $\mathbf{3 1 . 2}$ & $\mathbf{1 3}$ & $\mathbf{1 4 . 3}$ \\
Pheniramine & n.d. & $>100$ & n.d \\
Brompheniramine & 13.5 & 49.2 & n.d \\
Chlorpheniramine & 57.7 & 61.9 & n.d. \\
JNJ7777120 & n.d. & $>100$ & $>100$ \\
JNJ 10191584 & n.d. & n.d. & $>100$ \\
Thioperamide & $>100$ & $>100$ & n.d. \\
\hline
\end{tabular}

n.d., not determined. of isolated neutrophils DITH, LOR and JNJ7777120 were the most active compounds. Inhibition of ROS generation by antihistamines might beneficially contribute to the treatment of allergic noninfectious inflammation and support the treatment of acute exacerbation of pathological inflammation (Thurmond et al. 2008). It has been suggested that the suppression of CL by antihistamines is not a result of their direct scavenging activities; rather, it originates from their interference with calcium movement, enzyme pathways, or second messenger interaction (Lieberman 2002; Králová et al. 2006). However, compounds without any intracellular effect should not interfere with generation of ROS in neutrophils. Effect of antihistamines on intracellular CL with the rank order of potency: DITH > LOR > JNJ7777120 > JNJ 10195184 confirmed this suggestion, indicating a putative reduction in host defence against infectious components and redox-sensitive signal transduction (Kopprasch et al. 2003). Inhibition of CL due to DITH and LOR was accompanied by a decrease in superoxide generation and myeloperoxidase release from isolated neutrophils (Nosál' et al. 2006b).

Intracellular inhibition of ROS generation with antihistamines might impair innate immune responses to bacteria and should be used with caution in patients with severe bacterial infections (St Peter et al. 2010; Metz et al. 2011).

The difference between pheniramines might result from their halogenisation, as demonstrated by inhibition of oxidative burst of blood phagocytes during ischaemia/reperfusion (Jančinová et al. 2006; Nosál' et al. 2009b; Nosálová et al. 2009). Pheniramines, on the other side, decrease extracellular CL, which might indicate their ability to minimise the decrease in regulation of neutrophil functions and in microbial killing (Jančinová et al. 2006).

Significant differences were found between the drugs tested. Histamine did not affect stimulated whole blood CL. The difference between particular $\mathrm{H}_{1}$ antihistamines 


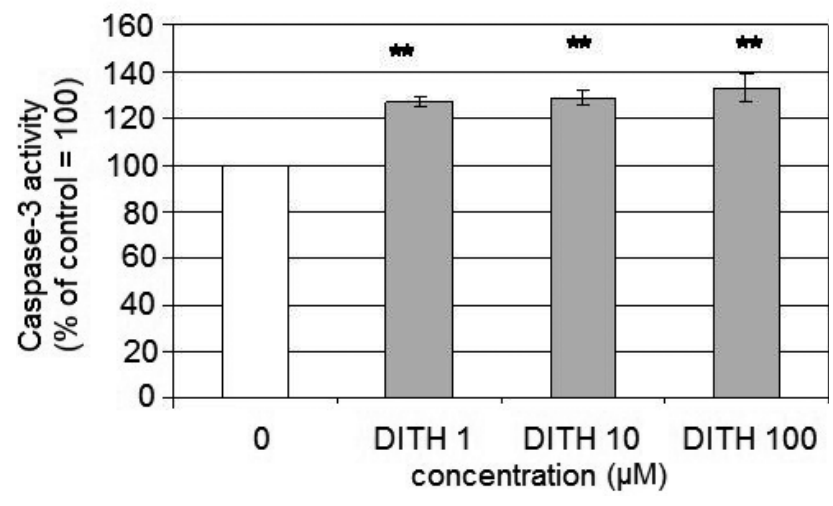

Figure 5. Effect of dithiaden (DITH) on activity of human recombinant caspase- 3 in cell-free system. Data are mean $\pm \operatorname{SEM}(n=4)$, ${ }^{* *} p>0.01$, DITH $(1,10,100 \mu \mathrm{M}) v s$. control $(0 \mu \mathrm{M})$.

resulted from the physico-chemical properties of particular drugs rather than from their specificity to affect histamine receptors, as demonstrated in platelets and neutrophils (Jančinová et al. 1995; Králová et al. 2009), as well as in the inhibition of ischaemia/reperfusion damage of vessels (Nosál' et al. 2009b; Nosál'ová et al. 2009). The non-receptor interaction of $\mathrm{H}_{1}$-antihistamines with oxidative burst was most probably due to their cationic amphiphilic structure (Nosál' et al. 2009a), underlying their ability to scavenge free radicals extracellularly and their ability to pass neutrophil membranes intracellularly. This was demonstrated in blood platelets with beta-adrenoceptor blocking drugs inhibiting platelet aggregation by changing the calcium movement and fluidity of their membranes (Nosál' et al 1985; Jančinová et al. 1996). In addition, in pharmacological non-toxic concentrations, $\mathrm{H}_{1}$-antihistamines significantly inhibited nitrite accumulation in RAW 264.7 cells which was not caused by the scavenging ability of the drugs against nitric oxide, yet the actual mechanism remains unclear (Králová et al. 2009). The degree of inhibition of nitrite accumulation positively correlated with the degree of lipophilicity tested, measured by reversed-phase thin layer chromatography. Furthermore, $\mathrm{H}_{1}$-antihistamines differentially modulated the iNOS protein expression (Králová et al. 2008, 2009). This was confirmed also for the ability of the $\mathrm{H}_{1}$-antihistamines tested to interfere with an extracellularly measured generation of free oxygen radicals.

DITH increased the activity of recombinant caspase in vitro in all concentrations tested ( 1 to $100 \mu \mathrm{M})$. Caspase- 3 belongs to the effector group of caspases, which are responsible for the executive phase of apoptosis (Fan et al. 2005). Caspases activation from their pro-caspase form has been widely described in apoptosis undergoing cells including neutrophils. Programmed cell death - apoptosis - is an important process for successful removal of recruited neu- trophils. Neutrophils express high levels of pro-apoptotic proteins (Fox et al. 2010; Witko-Sarsat et al. 2011). Activation of recombinant caspase- 3 by DITH might thus contribute to the inhibition of oxidative burst in human neutrophils resulting from suppression of PKC activation and to the antiinflammatory effect of DITH. A similar effect was described for natural stilbene derivatives on human neutrophils (Perečko et al. 2012).

DITH decreased PKC activation in PMA-stimulated neutrophils, indicating its interference with regulatory pathways of the oxidative burst in neutrophils. This finding might contribute also to the mechanism of the antioxidative effect of DITH in whole blood phagocytes and isolated neutrophils. Similar results were found in human gastric adenocarcinoma and Caski cells (Atten et al. 2001; Woo et al. 2004) and also for the polyphenolic compound $\mathrm{N}$-feruloylserotonin and resveratrol in human neutrophils (Nosál et al. 2011, 2014).

Thus DITH may interfere with modulation of intracellular signalling pathways involved in down-regulation of COX-2 and in iNOS expression and NF- $\mathrm{kB}$ activation, as demonstrated for resveratrol (Surh et al. 2001; Kundu et al. 2006).

Variability in ability of different antihistamines to interfere with stimulated CL at different sites of action is evident from $\mathrm{ED}_{50}$ values. The numbers for DITH and LOR are comparable to previously published data (Nosál' et al. 2009a).

In comparison with the $\mathrm{H}_{1}$ antihistamines tested, only compound JNJ777120 suppressed oxidative burst in whole
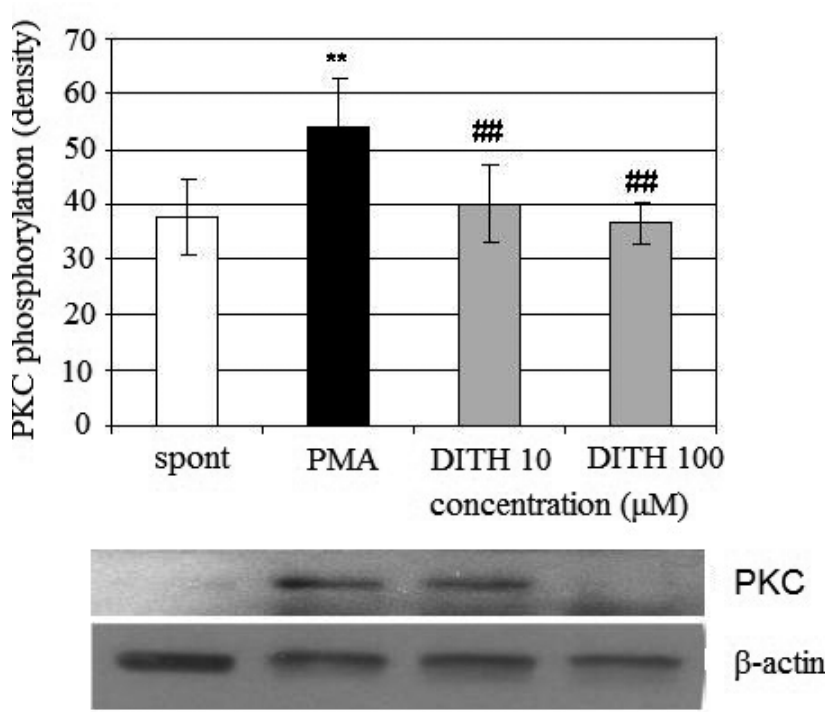

Figure 6. Protein kinase $\mathrm{C}$ (PKC) phosphorylation in PMA $(0.15 \mu \mathrm{M})$ stimulated isolated neutrophils treated with 10 and $100 \mu \mathrm{M}$ dithiaden. The values represent the percentage of resting control phosphorylated PKC isoenzymes ( $\alpha$ and $\beta \mathrm{II}$ ) detected by Western blotting and detected by phospho-PKC alpha/beta II (Thr638/64) antibody. Data are mean $\pm \operatorname{SEM}(n=4)$, ${ }^{* *} p>0.01$, \#\# $p \leq 0.01$. 
blood and in isolated neutrophils at both extra- and intracellular sites. Interestingly, this effect was not concentration-dependent. Compound JNJ 10191584 in $100 \mu \mathrm{M}$ concentration potentiated CL in whole blood, yet it inhibited CL intracellularly. Thioperamide was effective in the same concentration in whole blood but potentiated CL intracellularly. This effect may result from the chemical structure of the compounds tested: JNJ7777120 is methylpiperazin-indole, JNJ 10191584 benzimidazol-carbonyl-methylpiperazine and thioperamide cyclohexyl-imidazol-piperidinecarbothioamide and thus they differ from the chemical structure of $\mathrm{H}_{1}$-antihistamines tested.

The structure-activity relationship requires further detailed investigation. The antihistamines tested showed marked differences in the inhibition of oxidative burst in human blood and isolated neutrophils. It is evident from our results that compared with $\mathrm{H}_{3} / \mathrm{H}_{4}$ antihistamines; $\mathrm{H}_{1}$ antihistamines are much more potent in inhibiting stimulated chemiluminescence.

Acknowledgements. This work was supported in part by the project APVV-0052-10, APVV-0315-07 of the Slovak Research and Development Agency and by the grant VEGA 2/0010/13. The authors wish to thank Professor Magda Kouřilova for correcting the English grammar in the manuscript.

Conflicts of interest: The authors state no conflict of interest.

\section{References}

Atten M. J., Attar B. M., Milson T., Holian O. (2001): Resveratrol induced inactivation of human gastric adenocarcinoma cells through a protein kinase $\mathrm{C}$ mediated mechanism. Biochem. Pharmacol. 62, 1423-1432 http://dx.doi.org/10.1016/S0006-2952(01)00788-2

Celanire S., Wijtmans M., Talaga P., Leurs R., de Esche I. J. P. (2005): Keynote review: histamine $\mathrm{H} 3$ receptor antagonists for the clinic. Drug Discover. Today 10, 1613-1627 http://dx.doi.org/10.1016/S1359-6446(05)03625-1

Cheng K. C., Hsu J. Y., Fu L. S., Chang W. C., Chu J. J., Chi C. S. (2006): Influence of cetrizine and loratadine on granulocytemacrophage colony-stimulating factor and interleukin-8 release in A549 human airway epithelial cells stimulating with interleukin-1 beta. J. Microbiol. Immunol. Infect. 39, 206-211

Church M. K., Church D. S. (2013): Pharmacology of antihistamines. Indian J. Dermatol. 158, 219-224 http://dx.doi.org/10.4103/0019-5154.110832

Drábiková K., Perečko T., Nosál R., Bauerová K., Poništ S., Mihálová D., Kogan G, Jančinová V. (2009): Glucomanan reduces neutrophil free radical production in vitro and in rats with adjuvant arthritis. Pharmacol. Res. 59, 399-403 http://dx.doi.org/10.1016/j.phrs.2009.02.003

Fan T. J., Han L. H., Cong R. S., Liang J. (2005): Caspase family proteases and apoptosis. Acta Biochim. Biophys. Sin. (Shanghai) $37,719-727$ http://dx.doi.org/10.1111/j.1745-7270.2005.00108.x

Fox S., Leitch A. E., Duffin R., Haslett C., Rossi A. G. (2010): Neutrophil apoptosis: relevance to the innate immune response and inflammatory disease. J. Innate Immunol. 2, 216-227 http://dx.doi.org/10.1159/000284367

Gillard M., Chatelain P. (2006): Changes in pH differently affect the binding properties of histamine $\mathrm{H} 1$ receptor antagonists. Eur. J. Pharmacol. 530, 205-214 http://dx.doi.org/10.1016/j.ejphar.2005.11.051

Jančinová V., Petríková M., Májeková M., Nosál R. (1995): Effect of pheniramine, chlorpheniramine and brompheniramine on stimulated blood platelets: structure-activity relationships. Inflamm. Res. 44, S38-39 http://dx.doi.org/10.1007/BF01674385

Jančinová V., Nosál R., Danihelová E. (1996): On the effect of the antihistaminic drug bromadryl on human platelets in vitro. Inflamm. Res. 45, S21-23 http://dx.doi.org/10.1007/BF03354070

Jančinová V., Drábiková K., Nosál` R., Holomáňová D. (2006) : Extra- and intracellular formation of reactive oxygen species by human neutrophils in the presence of pheniramine, chlorpheniramine and brompheniramine. Neuroendocrinol. Lett. 27 (Suppl. 2), 141-143

Jančinová V., Perečko T., Nosál R., Koštálová D., Bauerová K., Drábiková K. (2009): Decreased activity of neutrophils in the presence of diferuloylmethane (curcumin) involves protein kinase C inhibition. Eur. J. Pharmacol. 612, 161-166 http://dx.doi.org/10.1016/j.ejphar.2009.03.080

Kopprasch S., Pietzsch J., Graessler J. (2003): Validation of different chemilumenic substances for detecting extracellular generation of oxygen species by phagocytes and endothelial cells. Luminescence 18, 268-273 http://dx.doi.org/10.1002/bio.737

Králová J., Číž M., Nosál' R., Drábiková K., Lojek A. (2006): Effect of $\mathrm{H} 1$ antihistamines on the oxidative burst of rat phagocytes. Inflamm. Res. 55, S15-16 http://dx.doi.org/10.1007/s00011-005-0020-6

Králová J., Nosál R., Drábiková K., Jančinová V., Denev P., Moravcová A., Kubala L., Č́žz M., Lojek A. (2008): Comparative investigations of the influence of $\mathrm{H} 1$-antihistamines on the generation of reactive oxygen species by phagocytes. Inflamm. Res. 57 (Suppl. 1), S49 http://dx.doi.org/10.1007/s00011-007-0624-0

Králová J., Račková L., Pekarová M., Kubala L., Nosál R., Jančinová V., Číž M., Lojek A. (2009): The effects of H1antihistamines on the nitric oxide production by RAW 264.7 cells with respect to their lipophilicity. Int. Immunopharmacol. 9, 990-995 http://dx.doi.org/10.1016/j.intimp.2009.04.005

Kundu J. K., Shin Y. K., Surh Y. J. (2006): Resveratrol modulates phorbol ester-induced pro-inflammatory signal transduction pathways in mouse skin in vivo: NF-kappaB and AP- 1 as prime targets. Biochem. Pharmacol. 72, 1506-1515 http://dx.doi.org/10.1016/j.bcp.2006.08.005

Leurs R., Church M. K., Tagliatella M. (2002): H1-antihistamines: Inverse agonists, anti-inflammatory actions and cardiac effects. Clin. Exper. Allergy 32, 489-498 http://dx.doi.org/10.1046/j.0954-7894.2002.01314.x 
Leurs R., Vischer H. F., Wijtmans M., de Esch I. J. P. (2011): An route to new blockbuster anti-histamines: surveing the offspring of the expanding histamine receptor family. Trends Pharmacol. Sci. 3, 250-257 http://dx.doi.org/10.1016/j.tips.2011.02.004

Lieberman P. (2002): Preclinical evidence of azelastine hydrochloride activity. Curr. Ther. Res. Clin. Exp. 63, 556-571 http://dx.doi.org/10.1016/S0011-393X(02)80061-3

Metz M., Doyle E., Bineslev-Jensed C., Watanabe T., Zuberbier T., Maurer M. (2011): Effects of antihistamines and innate immune responses to severe bacterial infection in mice. Int. Arch. Allerg. Immunol. 155, 355-360 http://dx.doi.org/10.1159/000321614

Nosál R., Jančinová V., Ondriaš K., Jakubovský J., Balgavý P. (1985): The interaction of beta-adrenoceptor blocking drugs with platelet aggregation, calcium displacement and fluidization of the membrane. Biochim. Biophys. Acta 821, $217-228$ http://dx.doi.org/10.1016/0005-2736(85)90090-2

Nosál'R., Jančinová V. (2002a) : Cationic amphiphilic drugs and platelet phospholipase A2 (cPLA2). Thromb. Res. 105, 339-345 http://dx.doi.org/10.1016/S0049-3848(02)00036-1

Nosál R., Drábiková K., Číž M., Lojek A., Danihelová E. (2002b): Effect of H1 antagonist DithiadenR on human PMN-leukocyte aggregation and chemiluminescence is stimulus-dependent. Inflamm. Res. 51, 557-562 http://dx.doi.org/10.1007/PL00012427

Nosál R. (2006a): On the antiplatelet and antileukocyte effect of cardiovascular, immunomodulatory and chemotherapeutic drugs. Cardiovasc. Hematol. Agents in Med. Chemistry 4, $237-261$ http://dx.doi.org/10.2174/187152506777698317

Nosál R., Drábiková K., Jančinová V., Mačičková T., Pečivová J., Holomáňová D. (2006b): On the pharmacology and toxicology of neutrophils. Neuroendocrinol. Lett. 27, 148-151

Nosál R., Drábiková K., Jančinová V., Moravcová J., Lojek A., Číž M., Mačičková T., Pečivová J. (2009a): H1-antihistamines and oxidative burst of professional phagocytes. Neuroendocrinol. Lett. 30, 133-136

Nosál R., Jančinová V., Nosálová V., Perečko T., Číž M., Lojek A. (2009b): Pheniramines and oxidative burst of blood phagocytes during ischaemia/reperfusion. Inflamm. Res. 58, S66-67 http://dx.doi.org/10.1007/s00011-009-2010-6

Nosál R., Perečko T., Jančinová V., Drábiková K., Harmatha J., Sviteková K. (2011): Naturally appearing N-feruloylserotonin isomers suppress oxidative burst of human neutrophils at protein kinase C level. Pharmacol. Rep. 63, 790-798 http://dx.doi.org/10.1016/S1734-1140(11)70591-6

Nosál R., Drábiková K., Jančinová V., Perečko T., Ambrožová G., Číž M., Lojek A., Pekarová M., Šmidrkal J., Harmatha J. (2014): On the molecular pharmacology of resveratrol on oxidative burst inhibition in professional phagocytes. Oxid. Med. Cell Longev. 2014, 706269 http://dx.doi.org/10.1155/2014/706269

Nosálová V., Drábiková K., Jančinová V., Nosál R., Mačičková T., Pečivová J., Nedelčevová J., Sotníková R. (2009): Protective effect of pheniramines against mesenteric ischaemia/reperfusioninduced injury. Inflam. Res. 58, S68-69

http://dx.doi.org/10.1007/s00011-009-2011-5

Passani M. B., Blandina P. (2011): Histamine receptors in the CNS as targets for therapeutic intervention. Trends Pharmacol. Sci. 32, 242-249

http://dx.doi.org/10.1016/j.tips.2011.01.003

Parsons M. E., Ganellin C. R. (2006): Histamine and its receptors. Br. J. Pharmacol. 147, S127-135 http://dx.doi.org/10.1038/sj.bjp.0706440

Perečko T., Drábiková K., Račková L., Číž M., Podborská M., Lojek A., Harmatha J., Šmidrkal J., Nosál R., Jančinová V.(2010): Molecular targets of the natural antioxidant pterostilbene: effect on protein kinase C, caspase-3, and apoptosis in human neutrophils in vitro. Neuroendocrinol. Lett. 31, 101-107

Perečko T., Drábiková K., Nosál R., Harmatha J., Jančinová V.(2012): Involvement of caspase-3 in stilbene derivatives induced apoptosis of human neutrophils in vitro. Interdisc. Toxicol. 5, 76-80

Smiths R. A., Leurs R., de Esch I. J. P. (2009): Major advances in the development of histamine H4 receptor ligands. Drug Discover. Today 14, 746-753

St Peter S. D., Sharp S. W., Ortlie D. J. (2010): Influence of histamine receptor antagonists on the outcome of perforated apendicitis: analysis from a perspective trial. Arch. Surg. 145, 143-146 http://dx.doi.org/10.1001/archsurg.2009.258

Surh Y. J., Chun K. S., Cha H. H., Han S. S., Keum Y. S., Park K. K., Lee S. S. (2001): Molecular mechanisms underlying chemopreventive activities of anti-inflammatory phytochemicals: down-regulation of COX-2 and iNOS through suppression of NF-kappa B activation. Mutat. Res. 480-481, 243-268 http://dx.doi.org/10.1016/S0027-5107(01)00183-X

Thurmond R. L, Gelfand E. W., Paul J., Dunford P. J. (2008): The role of histamine $\mathrm{H} 1$ and $\mathrm{H} 4$ receptors in allergic inflammation: the search for new antihistamines. Nature Rev. Drug Discovery 7, 41-53

http://dx.doi.org/10.1038/nrd2465

Wang L. F. (2009): Halogenation effects of pheniramines on the complexation with beta-cyclodextrin. J. Pharm. Biomed. Anal. 50, 392-396 http://dx.doi.org/10.1016/j.jpba.2009.05.027

Witko-Sarsat V., Pederzoli-Ribeil M., Hirsch E., Sozzani S., Cassatella M. A. (2011): Regulating neutrophil apoptosis: new players enter the game. Trends Immunol. 32, 117-124 http://dx.doi.org/10.1016/j.it.2011.01.001

Woo J. H., Lim J. H., Kim Y. H., Suh S. I., Min D. S., Chang J. S., Lee Y. H., Park J. W., Kwon T. K. (2004): Resveratrol inhibits phorbol myristate acetate induced matrix metalloproteinase- 9 expression by inhibiting JNK and PKCd signal transduction. Oncogene 23, 1845-1853

http://dx.doi.org/10.1038/sj.onc.1207307

Received: September 2, 2014

Final version accepted: November 28, 2014

First published online: March 2, 2015 